\title{
Dasar-Dasar Konstitusional Pembentukan \\ Peraturan Daerah
}

\author{
Oleh : \\ Dr. Faisal Akbar Nasution, S.H., M.Hum \\ (Ketua Ombusmen Sumut)
}

\begin{abstract}
Abstrak
Didalam UUD 1945 sekurang-kurangnya terdapat 2 (dua) sendi sebagai dasar konstitusional pembentukan peraturan perundang-undangan, yaitu sendi kerakyatan (demokrasi) dan sendi negara berdasarkan atas hukum. Kegiatan membentuk peraturan perundang-undangan merupakan tugas pertama dan utarna didalam membangun sistem ketatanegaraan yang demokratis. Kehadiran lembaga perwakilan rakyat merupakan suatu keniscayaan didalam negara demokrasi, dimana dengan prinsip perwakilan ini, lembaga perwakilan rakyat memiliki legitimasi dari seluruh rakyat untuk menjalankan hak dan kewajiban rakyat dalam berbagai bidang kehidupannya yang dapat terlihat dari berbagai peraturan perundang-undangan yang dibentuk untuk mengatur hak dan kewajibannya, sehingga prinsip bahwa seluruh peraturan perundang-undangan harus dibentuk secara demokratis dapat diwujudkan.
\end{abstract}

Kata Kunci : Lembaga Penvakilan Rakyat, Peraturan Perundang-Undangan 


\section{A. Pendahuluan}

Secara filosofis, sosiologis, dan politis, pembentukan sebuah peraturan perundang-undangan agar memiliki keab sahan dan akar yang kuat serta memiliki kaidah yang jelas secara teknik perun dang-undangan, harus mem iliki sendi atau dasar yang kuat supaya peraturan perundang-undangan itu ditaati atau dipatuhi oleh masyarakat.

$\begin{array}{rr}\text { Berdasarkan } & \text { pemikiran } \\ \text { tersebut, didalam UUD } 1945\end{array}$ sekurang-kurangnya terdapat 2 (dua) sendi sebagai dasar konstitusional pembentukan peraturan perundangundangan, yaitu sendi kerakyatan (demokrasi) dan sendi negara berdasarkan atas hukum. Bagaimana pemahaman terhadap kedua sendi tersebut akan dibahas selanjutnya dibawah ini.

\section{B. Sendi Kerakyatan (Demokrasi) Dasar kerakyatan di dalam}

UUD 1945 tertuang dalam sila ke empat yang berbunyi "Kerakyatan yang dipimpin oleh hikmah kebijaksanaan dalam permusyawaratan/perwakilan", dan didalam batang tubuh UUD 1945 ditemukan lagi pada ketentuan yang terdapat pada Pasal 1 ayat (2) yang telah diamandemen pada Perubahan ketiga UUD 1945 tahun 2001 yang berbunyi "Kedaulatan berada ditangan rakyat dan dilaksanakan menurut Undang-Undang Dasar".

Lembaga perwakilan rakyat sebagai lembaga negara yang

terpenting dalam sistem ketatanegaraan, merupakan lembaga negara yang mencerminkan apakah negara itu dapat dikatakan sebagai sebuah negara demokrasi atau tidak, keberadaan lembaga negara tersebut merupakansuhan negara kesatuan dan menerapkan sistem atau asas desentralisasi sebagai salah satu asas terpenting dalam penyelenggaraan

urusan pemerintahan, maka pelaksanaan sistem pemerintahan demo krasi ini, juga harus diterapkan pada tingkat pemerintahan daerah sebagaimana diatur di dalam Pasal 18 UUD 1945.

Oleh karena itu prinsip keterwakilan yang ada di pusat diterapkan pada tingkat pemerintah daerah. Dengan demikian kehadiran

DPRD merupakan perwujudan pelaksanaan ajaran kedaulatan rakyat pada tataran pemerintahan daerah.

Desentralisasi sebagai salah satu asas penyelenggaraan pemerintahan daerah pada gilirannya menurunkan pengertian otonomi, yaitu merupakan suatu hak atau wewenang dan kewajiban sesuatu daerah otonom untuk mengurus dan mengatur sendiri urusan rumah tangganya sesuai dengan peraturan perundang-undangan yang berlaku.

Untuk menyelenggarakan otonomi, pemerintah pusat menyerahkan sejumlah urusan pemerintahan yang menjadi urusan rumah tangga daerah harus selalu berorientasi pada peningkatan kesejahteraan masyarakat dengan memperhati kan aspirasi yang tumbuh dalam masya rakat dan harus menjamin keserasian hubungan antara daerah dengan daerah lainnya, dalam rangka meningkatkan pelayanan terhadap masyarakat dan pelaksanaan pembangunan secara 
merata di seluruh wilayah Negara Indonesia.

Dengan diserahkannya sesuatu urusan menjadi urusan rumah tangga daerah, mengandung arti bahwa pembuatan keputusan sesuatu

urusan pemerintahan bergeser ketahap yang lebih rendah, yakni dimana keputusan tersebut dibuat oleh perangkat pemerintah daerah.

Dengan demikian adanya penyerahan urusan-urusan pemerintahan mengandung maksud bahwa masyarakat daerah melalui aparatur pemerintahan daerahnya diberi kepercayaan dan kesempatan untuk ikut serta dalam penyelenggara pemerintahan khususnya di daerah.

Atau dalam bahasa lain sebagaimana dikatakan Laode Ida bahwa eksistensi pemberian otonomi kepada daerah pada hakekatnya menjadikan daerah dalam sistem

pemerintahan yang demokratis sebagai subyek untuk menentukan dirinya sendiri. Dalam konteks inilah, seperti dikatakan Laode Ida selanjutnya, otonomi pada dasarnya mewujudkan self-governance, dan self-legislation.

Dengan mewujudkan selfrule dan selflegislartion seperti dimaksud Laode Ida, berarti pemerintahan darah berhak untuk membuat pengaturan terkait dengan otonomi yang dimilikinya. Oleh sebab itu perangkat pemerintahan daerah seperti Kepala Daerah dan DPRD sebagai pengejawantahan pelaksanaaan asas demokrasi padatingkatpemerintahan daerah sangat berperan sebagai pilar demokrasi pada tataran masyarakat yang paling bawah (grass root) di dalam wilayah Negara Republik Indonesia yang sedemikian luas ini.

Untuk mewujudkan aspirasi dan kepentingan rakyat di daerah, maka perlulah peraturan perundangundangan yang mengatur tata kehidupan rakyat dalam berbagai bidang kehidupan sejalan dengan otonomi yang dimiliki daerah, bentuk peraturan itu adalah peraturan daerah (Perda).

Perda secara konstitusional diakui sebagai salah satu bentuk peraturan perundang-undangan di dalam sistem perundang-undangan nasional. Hal ini bisa dilihat dari ketentuan Pasal 18 ayat (6) UUD 1945 yang menegaskan bahwa

"Pemerintahan daerah berhak menetap kan peraturan daerah dan peraturan-pera turan lain untuk melaksanakan otonomi dan tugas pembantuan".

Keberadaan perda diatur lebih lanjut dalam UU Nomor 10 Tahun 2004 tentang Pembentukan Peratuaran Perundang-undangan yang telah mengatur tentang sumber hukum dan tata urutan pe raturan perundang-undangan yang berlaku di Negara Republik Indonesia. Ada pun tata urutan peraturan perundangundangan sebagaimana diatur dalam Pasal 7 ayat (1) UU Nomor 10 Tahun 2004 tersebut di atas adalah sebagai berikut :

1. Undang-UndangDasar Negara Republik Indonesia Tahun 1945;

2. Undang-Undang/Peraturan pemerintah Pengganti Undang-Undang;

3. Peraturan Pemerintah;

4. Peraturan Presiden;

5. Peraturan Daerah; 
Dengan keberadaan perda sebagai mana diatur dalam UUD 1945 dan UU Nomor 10 Tahun 2004 di atas, menegaskan kepada kita bahwa kedudukan sebuah perda amatlah

penting dalam tatanan sistem ketatanegaraan dan sistem perundang-undangan nasional, karena perda mempunyai dasar legalitas yang amat kuat untuk mengatur berbagai hal yang berkaitan dengan pelaksanaan berba gai urusan pemerintahan yang telah men jadi otonomi daerah sebagai bagian dan pelaksanaan sistem pemerintahan nasio nal, meskipun ruang lingkup dan daya berlakunya hanya terbatas pada masyarakat yang berdiam pada daerah dimana peraturan daerah itu dikeluarkan.

Kedudukan perda kemudian diatur lebih lanjut di dalam UU Nomor 32 Tahun 2004 tentang Pemerintahan Daerah, dimana pada Pasal 136 ayat (1) dise butkan "Peraturan daerah ditetapkan oleh Kepala Daerah setalah mendapat persetujuan bersama DPRD".

Ketentuan ini menegaskan bahwa pembentukan perda melibatkan 2 (dua) in stitusi pemerintahan daerah yang terdapat pada masing-masing daerah, yaitu Kepa la Daerah dan DPRD. Dalam hal ini sebuah perda tidak bisa berlaku bila hanya ditetapkan oleh salah satu lembaga peme rintahan daerah,

melainkan harus melibatkan sekaligus kedua institusi pemerintahan daerah tersebut, yaitu kepala daerah dan DPRD.

Instrument ini sama halnya dengan kelahiran undang-undang pada tingkat pemerintah pusat, yakni hanya berlaku bila telah mendapatkan persetujuan bersama antara Presiden dan DPR. Artinya perwujudan ajaran demokrasi juga harus diberlakukan sama pada setiap tingkatan pemerintahan, jadi bukan hanya berlaku pada tataran pemerintahan nasional saja.

Di dalam praktek pembentukan pera turan perundang-undangan, tidak semua jenis peraturan perundangundangan dapat dibentuk melalui lembaga perwakilan rakyat, karena dalam berbagai hal terten to para anggota lembaga perwakilan rakyat ini memiliki banyak tugas dan fungsi yang harus dilaksanakannya, yakni disam ping membentuk undangundang (DPR) atau peraturan daerah (DPRD) bersama-sama dengan fihak eksekutif (pusat mau pun daerah), para anggota lembaga per wakilan rakyat ini juga mempunyai tugas yang cukup penting

yaitu melakukan pengawasan (controlling) atas jalannya pemerintahan yang dilakukan oleh lem baga eksekutif dan pengawasan terhadap penggunaan anggaran belanja negara/ daerah (budgeting) yang dilakukan pi hak eksekutif, yang juga harus dilakukan oleh para anggota lembaga perwakilan rakyat.

Berkaitan dengan tugas pembantuan seperti dimaksud pada nomor 3 (tiga) diatas, sebuah perda dapat dibuat oleh pemerintah daerah yang bersangkutan hanya menyangkut hal-hal yang secara tegas berhubungan dengan tugas yang telah ditetapkan dan diserahkan peme rintah pusat yang menugaskannya kepada daerah yang bersangkutan untuk melak sanakan urusan pemerintahan pusat mela lui tugas pembantuan (medebewind). Di luar dari hal-hal yang menjadi urusan 
tugas pembantuan tersebut, sudah tentu tidak dapat dibuatkan perdanya.

\section{Penutup}

Sejalan dengan sendi kerakyatan, peraturan perundangundangan harus dibentuk secara demokratis. Karena itu secara material tidaklah dapat dipisahkan antara sendi kerakyatan dengan sendi negara berdasarkan atas hukum.

Negara seperti ini lajim disebut sebagai negara hukum yang demokratis. Prinsip kesatuan antara sendi kerakyatan dengan sendi negara berdasarkan atas hukum ini pernah ditegaskan dalam UUD Sementara 1950 yang menyebutkan "Rerpublik Indonesia yang merdeka dan berdaulat ialah suatu negara hukum yang demokratis dan berbentuk kesatuan".

Sejalan dengan pemikiran diatas, maka dalam setiap pembentukan sebuah perda, prinsip demokrasi sejauh mungkin segera dilaksanakan. Hal ini menyiratkan bahwa dalam pembentukan sebuah perda harus terlibat rakyat melalui wakil-wakil mereka di DPRD.

Bahkan didalam UU Nomor 10 Tahun 2004 keikutsertaan atau partisipasi masyarakat secara langsung terlibat dalam proses pembentukan peraturan perundang-undangan dimungkinkan. Hal ini misalnya dapat dilihat dalam Pasal 53

UU Nomor 10 Tahun 2004 yang menegaskan "Masyarakat berhak mem berikan masukan secara lisan atau tertulis dalam rangka penetapan maupun pemba hasan rancangan undang-undang dan rancangan peraturan daerah".

Ketentuan yang hampir sama khu susnya yang berkaitan dengan perda da pat dilihat pada ketentuan Pasal 139 ayat (1) UU Nomor 32 Tahun 2004 yang menyatakan bahwa "Masyarakat berhak memberikan masukan secara lisan atau tertulis dalam rangka penyiapan atau pembahasan rancangan peraturan daerah".

Berdasarkan kedua undangundang diatas, nyatalah bagi kita bahwa dalam proses pembentukan sebuah rancangan undang-undang dan rancangan perda, masyarakat sebagai objek hukum dari kedua peraturan perundang-undangan ter sebut tidak lagi berkedudukan sebagai obyek dalam proses pembentukannya, tetapi juga berperan sebagai subyek dan ikut terlibat dalam proses pembentukan peraturan perundang-undangan tersebut.

Bahkan dimungkinkan masyarakat dapat berperan langsung untuk menyusun rancangan perda ditingkat pemerintahan daerah agar dapat diajukan lebih lanjut kepada kepala daerah atau melalui anggota DPRD yang selanjutnya akan mengusulkannya untuk dibahas dalam lembaga perwakilan rakyat didaerah tersebut, sebagaimana halnya belakangan ini telah banyak

rancangan undang-undang dan bahkan rancangan perda yang dibuat oleh elemen masyarakat untuk diajukan menjadi undang-undang atau perda melalui meka nisme yang ada untuk selanjutnya digodok

dilembaga perwakilan rakyat bersama-sama dengan pihak pemerintah untuk mendapatkan

persetujuan bersama, yang selanjutnya akan disahkan oleh pemerintah. 


\section{DAFTAR PUSTAKA}

Ida Laode,Desentralisasi Dan Demokrasi. dalam jurnal Demokrasi dan HAM, Vol. 2 Nomor 2 Juni September 2002

Lubis M. Solly,Landasan dan Teknik Perundang - Undangan. Mandar Maju, Bandung, 1989

Manan Bagir, Dasar - Dasar Perundang - Undangan Indonesia. In-Hill Co, Jakarta, 1992

Nasution Faisal Akbar, Dasar - Dasar Teknik Penyusunan Perundang - Undangan, USU Press, Medan, 1998 ..Dimensi Hukum Dalam Penzerintakan Daerah, Kajian KritisAtasUU No. 22 Tahun 1999, Pustaka Bangsa Press. Medan, 2003 .Ketatanegaraan Republik Indonesia Pasca Amandemen UUD 1945, Dinas Pendidikan Provinsi Sumatera Utara, Medan, 2006

Rodee Carlton Clymer (et all), Pengantar Ilmu Politik, Terjemahan Zulkifly Hamid, Rajawali Press, Jakarta, 1988

Rondinelli D.

Local Organization For

A. dam Ruddle K., Integrated Rural Devolepment :Implementi ng Equity Policy In Developing Countries, International Review ofAdministrative Science, No. 1.1997 